\title{
КОМУНІКАТИВНО-ПРАГМАТИЧНИЙ ПОТЕНЦІАЛ ІНТЕРОГАТИВІВ АНГЛОМОВНОЇ НАУКОВОЇ СТАТТІ
}

У статті з'ясовано прагматичний потенціал інтерогативних конструкиій як специфічних мовних формул реалізації аргументативної стратегї̈ англомовної науковій статті. На матеріалі ста наукових статей, із яких методом суцільної вибірки було вилучено двісті чотири інтерогативи, визначено типологію власне інтерогативних конструкиій в англомовних наукових статтях гуманітарної сфери, проаналізовано частоту вживання різних типів інтерогативів у реалізаиії основних тактик аргументативної стратегії наукового дискурсу.

Ключові слова: аргументативна стратегія, тактика, науковий дискурс, інтерогатив.

Постановка проблеми у загальному вигляді та їі зв'язок із важливими науковими і практичними завданнями. Нинішній етап розвитку лінгвістичної науки позначений значною зацікавленістю дослідників проблемами тексту загалом та наукового дискурсу зокрема. Така ситуація $є$ невипадковою, адже зумовлена вона складною, різноаспектною природою об'єкта дослідження, пошуком нових методів його вивчення, а також інтеграційними та глобалізаційними процесами як у власне мовознавчій методології, так і у світоглядних способах наукового пізнання.

Мова науки постає доволі складним для теоретичної кваліфікації явищем, оскільки змістовно конденсує низку проблемних $\mathrm{i}$ неоднозначних щодо кваліфікаційних вимірів аспектів, що відбивають різноконцептуальні підходи до витлумачення наукових текстів [1].

Так, зокрема, відносно усталеною на сьогодні є позиція, за якої текст і дискурс постають різними аспектами комунікації, за умови що дискурс розглядають як окремий мовленнєвий акт комунікації, в процесі якого на соціальному тлі відбувається породження тексту як знакової моделі. За такого підходу текст - це і частина дискурсу, і знаковий аспект комунікації, тоді як дискурс наділений діяльнісними ознаками. У пропонованому аспекті актуальними видаються питання реалізації комунікативнопрагматичних стратегій і тактик у різних типах дискурсивних практик, зокрема у сфері наукового дискурсу.

Традиційно наукову мову розглядають у контексті інституційного дискурсу, тобто комунікації, обмеженої певними соціальними інститутами, де кожен із учасників виконує певну соціальну роль. Основне призначення наукового дискурсу полягає в демонструванні істинності авторської позиції на шляху до пізнання об'єкта наукового дослідження. Будуючи наукові висловлювання, автор спрямовує зусилля на максимальне зацікавлення й переконання сприймача (адресата) в правильності висловлюваних думок. Аргументація авторської позиції в науковому дискурсі спирається на низку типових для наукової мови різнорівневих засобів, що слугують реалізації стратегічно-тактичних намірів адресанта. Відповідно автори наукових текстів прагнуть віднайти найбільш ефективні способи посилення аргументації, акцентування змістових домінант наукової дискусії, увиразнення причиново-наслідкових зв'язків, дотримання точності та неупередженості викладу. При цьому традиційні, типові для наукової комунікації способи ії побудови (логічність, зв'язність, номінативна цілісність термінологічних одиниць тощо) доповнюються, на перший погляд, нетиповими для наукової комунікації експресивними засобами, покликаними увиразнити авторську дослідницьку позицію. Іншими словами, домінантні вирізнювальні ознаки наукового дискурсу знаходять реалізацію не лише в типових, "стриманих", "спокійних" лексико-синтаксичних одиницях, але й у релевантних для наукової комунікації підсилювальних одиницях, націлених на забезпечення "інтелектуально-емоційної напруженості викладу" (термін Н. В. Данилевської) [2].

Окреслені попереду проблемні питання у сьогоденній лінгвістиці не знайшли остаточного розв'язання, що актуалізує їхнє дослідження в площині нашої праці. I якщо віднесеність наукового дискурсу до інституціонального наразі не викликає глибоких суперечок, оскільки дослідники схильні до думки, що в процесі наукової комунікації породжується особливий тип спілкування із характерним для нього високим ступенем впливу на реципієнта, то з'ясування механізмів наукової аргументації потребує більш детального 
аналізу. Актуальним залишається також питання пошуку оптимальних тактик аргументації для верифікації наукової інформації задля її органічної вбудови в наукову картину світу.

Аналіз основних досліджень і публікацій із зазначеної проблеми. Науковий дискурс як особливий вид інституційного дискурсу був предметом дослідження у різних наукових парадигмах, що дало змогу використати надбання попередників як теоретико-методологічну основу для власного наукового аналізу. Мову науки розглядали в аспекті структури, прагматики та функцій (праці Н. М. Разинкіної, I. М. Колегаєвої, В. І. Карабана, .М.Ільченко, С. В. Шепітько, Т. В. Яхонтової, А. Крісмора, Р. Фарнсворса, А. Скулстада та ін.), що, однак не применшує необхідність їі подальшого вивчення. Учені зазначають, що науковий дискурс можна кваліфікувати як особливий тип взаємодії, в основі якої лежать комунікативні стратегії і тактики, які мовець використовує задля впливу на свого адресата, і які відбивають як загальні типологічні, так і етноспецифічні особливості (О. Ільченко).

Комунікативно-прагматичний фокус дослідження наукового дискурсу спрямовано не лише на мовне оформлення стратегій і тактик як формувальних чинників наукового спілкування, але й на категоріальну наповненість наукових текстів, зокрема особливості реалізації авторизації, адресації, інтертекстуальності, оцінності, експресивності та інших комунікативних категорій. Із-поміж зазначених найбільш неоднозначною в аспекті наукової мови виступає категорія експресивності. Цілком погоджуємося із українською дослідницею М. П. Баган, яка зауважує: "... мова науки зорієнтована не на емоційно-чуттєве, а на логічне сприйняття, максимальну точність, стрункість та неупередженість викладу" [3: 9]. Не можемо оминути увагою і той факт, що в сучасних мовознавчих дослідженнях співіснують різні підходи щодо можливості та доцільності експресивного забарвлення наукових текстів. Одні схильні вважати, що експресивність не типова для наукової мови, і навіть стає на заваді об'єктивному викладу матеріалу (Н. А. Ковальська, Г. Онуфрієнко) [4; 5]. Натомість, низка мовознавців (Н. Ф. Непийвода, О. Д. Пономарів, С. Я. Срмоленко та ін.) висловлюють думку про неминучість використання в наукових текстах експресивних мовних засобів, покликаних увиразнити дослідницьку позицію. На користь такої думки висувається теза про синкретичність людського пізнання й наукової діяльності, яку визначають не лише логічні операції, але й "емоція, воля й інтуїція" [6: 168; 7].

Імпонує думка М. П. Баган про можливість експресивного забарвлення наукового дискурсу як важливого чинника побудови аргументованого й переконливого наукового викладу. Експресія, на ії думку, "з одного боку, засвідчує наукову компетентність мовця, його впевненість у власній концепції, а з іншого, це прагматично зорієнтована категорія наукового викладу, основне навантаження якої полягає в максимальному впливові на сприймача - зацікавленні й переконанні його в правильності висловлюваних думок" [3: 10].

Окреслення невирішених питань, порушених у статті. Слід зауважити, що спектр нетипових для наукових текстів мовних засобів лише нещодавно став предметом спеціальних розвідок у вітчизняній та зарубіжній лінгвістиці (див. праці М. П. Баган, Н. Ф. Непийводи, О. Д. Пономаріва, С. Я. Єрмоленко, Н. А. Ковальської, П. О. Селігей, V. Cortes, М. А. К. Halliday, J. M. Swales та ін.) [8; 9]. Такі праці наштовхують на думку про те, що наукова комунікація як одна з найбільш регламентованих інституційних дискурсивних практик схильна до порушення усталених правил на користь існування девіаційних виявів організації наукової комунікації. У цьому аспекті варто згадати відомі поняття т.зв. трьох заборон, уведені X. Вайнріхом для позначення відносно рідко вживаних у мові науки текстотвірних елементів: заборона на авторизацію, наративна заборона, заборона на метафору [10: 232-238]. У контексті сучасних мовознавчих досліджень висловлені вченим думки знаходять продовження. Проте дослідники стверджують, що низька частотність таких структур "працює" на збільшення їхнього прагматичного потенціалу, що, у свою чергу, створює позитивне тло для розвитку діалогічності наукового опису. 3 певним обмеженням питальні конструкції також можна визнати т.зв. "заборонними" елементами наукового дискурсу. Інтерогативи наукового дискурсу залишаються остаточно не вивченими як із позицій їхнього типологічного варіювання у структурі наукової статті, так і з огляду реалізації ними різних стратегій і тактик наукового дискурсу. Висловлені міркування визначають актуальність пропонованого дослідження інтерогативів як нетипових, проте прагматично насичених мовних формул реалізації аргументативної стратегії в англомовній науковій статті як жанровому різновиді наукового дискурсу.

Мета нашої роботи полягає у з'ясуванні прагматичного потенціалу інтерогативних конструкцій як специфічних мовних формул реалізації стратегії аргументації у структурі англомовної наукової статті. Основними робочими завданнями були наступні: 1) визначити типи власне інтерогативних конструкцій в англомовних наукових статтях гуманітарного спрямування; 2) проаналізувати частоту вживання різних типів інтерогативів у структурних частинах наукової статті; 3) з'ясувати, на реалізацію яких комунікативних стратегій працюють інтерогативи в текстах англомовних наукових статей; 4) встановити прагматичний потенціал інтерогативів англомовних статей як засобів реалізації основних тактик аргументативної стратегії наукового дискурсу.

Матеріал дослідження. До аналізу було залучено 100 наукових англомовних статей із сучасних англомовних журналів гуманітарної сфери, розміщених у відкритих он-лайн ресурсах. Зокрема, статті було 
знайдено на веб-сторінках таких видань: "Applied Linguistics" (https:/academic.oup.com/applij), "Applied Psycholinguistics" (https://www.cambridge.org/core/ journals/ applied-psycholinguistics), "Bilingualism: Language and Cognition" (https://www.cambridge.org/core/journals/bilingualism-language-and-cognition), "Computational Linguistics" (https://www.mitpressjournals.org/loi/coli), "Gender and "Canguage" (https://journals.equinoxpub.com/index.php/GL), "Glossa" (https://www.glossa-journal.org), "International Journal of Language \& Literature" (http://ijll-net.com), "International Journal of Linguistics \& Communication" (http://dx.doi.org/10.15640/ijlc.v6n2a1), "Journal of Child (https://www.cambridge.org/core/journals/journal-of-child-language), "Journal of Communication Disorders" (https://www.journals.elsevier.com/journal-of-communication-disorders), "Journal of Language and Linguistic Studies" (https://www.jlls.org/index.php/jlls), "Journal of Phonetics" (https://www.sciencedirect.com/journal/journal-of-phonetic), "Journal of Pragmatics" (https://www.sciencedirect.com/journal/journal-of-pragmatic), "Journal of Semantics" (https://academic.oup.com), "Language \& Communication" (www.sciencedirect.com/journal/language-and-communication), "Language Sciences" (https://www.sciencedirect.com/journal/language-science), "Linguistic Typology" (https://www.degruyter.com/view/j/lity), "Linguistics and Education" (https://www.sciencedirect.com/journal/linguistics-and-education), "Semiotica" (https://www.degruyter.com/view/j/semi), "Text\&Talk" (https://www.degruyter.com/view/j/text). Загалом iз журнальних статей методом суцільної вибірки було виділено та проаналізовано відповідно до поставлених завдань 204 власне питальних конструкції.

Виклад основного матеріалу з обгрунтуванням отриманих наукових результатів. Проаналізувавши тексти 100 англомовних статей гуманітарної сфери на предмет наявності в них інтерогативних конструкцій як специфічних мовних формул реалізації комунікативних стратегій і тактик наукового дискурсу нами було виявлено низку особливостей таких питальних речень щодо їхньої спроможності виступати експлікаторами комунікативно-прагматичних тактик. Результати наших спостережень наводимо нижче.

Насамперед зазначимо, що загальна кількість інтерогативів в аналізованих статтях є обмеженою (204 одиниці). Більше того, власне питальні конструкції було виявлено лише в 78 із 100 наукових статей. Тобто $22 \%$ досліджуваного матеріалу не містило жодної інтерогативної конструкції. При цьому в 54 статтях (що складає 69,2 \% від усієї кількості статей із інтерогативами) було зафіксовано використання двох питальних конструкцій, у 16 (20,5 \%) - трьох інтерогативів і лише у 8 статтях (10,3 \%) функціонувало чотири і більше питальні конструкції. Наведені числові показники підтверджують загальновизнану тезу про клішовану нетиповість питальних речень для наукового писемного дискурсу. Така ситуація обумовлена декількома факторами. По-перше, питальні конструкції загалом є обмеженими в писемній формі спілкування через віддаленість у просторі адресата та адресанта та відтермінованість у часі взаємодії між ними, оскільки питання здебільшого вимагає безпосередньої зворотної реакції. Природнім комунікативним простором для інтерогативів $є$ діалогічний дискурс і канонічні ситуації безпосереднього контакту комунікантів. По-друге, лінгвальна природа питальних речень до певної межі протирічить комунікативним принципам наукового спілкування: у науці не опитують реципієнту аудиторію, а пропонують власні відповіді. Хоча а пріорі науковий дискурс просякнутий категорією питальності, яка, набуваючи ознак проблемності, створює модально-інтенційний каркас цілісної наукової інтеракції. Попри це, власне питальних структур у науковому дискурсі вкрай мало, оскільки вони не вписуються в прагматичний контекст науковопізнавальної ситуації і не використовуються настільки широко, як у діалогічних практиках. 3 огляду на це, використання питальних конструкцій у науковому дискурсі є дієвим інструментом актуалізації наукової дискусії.

Виокремлені нами прямі питальні конструкції типологічно представлено різноструктурними власне питаннями (із стандартною семантикою питальності), риторичними питаннями, а також діалогічними єдностями.

Власне питання (загальні, спеціальні, розділові, альтернативні та ін.) привертають увагу приймача, спонукають до спільної мисленнєвої діяльності, уводять елементи полеміки, створюючи тим самим діалогічність:

What are the functional categories when the present perfect appears in narrative or explication embedded within one person's turn at talk? (Text\&Talk);

This result raises a deeper question about the role and status of 'backwards' direction rules: if speakers rely primarily on forward rules, why would the grammar additionally contain backward rules that are used simultaneously, but to a lesser extent? We can only offer tentative speculation on this point? (Journal of Language and Linguistic Studies).

Риторичні питання як вузькоспеціалізовані засоби експлікації питальної модальності через порушення кореляції "питання - відповідь" мають на меті привернути увагу реципієнта, наблизити його до автора, передавши водночас аксіологічність та категоричність судження, створивши уявну ситуацію діалогу:

Does it make sense to let the position in an ordered list represent the semantic role of an argument in a predication? Consider the following examples in which arguments are interchanged (Computational Linguistics). 
Специфіка діалогічних комплексів (єдностей) полягає у створенні імітації діалогічної практики, в якій комунікантами виступає як автор, так і реципієнта аудиторія. При цьому автор будує комунікативну стратегію двома шляхами: він або подає інформацію у стрункому каркасі "питання - відповідь", або створює діалогічну ситуацію, коли відповідь на сформульоване питання треба шукати в наступному тексті, з'ясовуючи авторську позицію щодо проблемної ситуації:

Assumptions about headshaking that underlie the proposed typology of negation in SL are a case in point. It is claimed that headshaking during negation in SLs has grammaticalised and is not gestural. But is this accurate? As we have seen, the data presented here suggest that this appears not to be the case for Auslan. It is possible that larger representative datasets of other SLs may reveal that Auslan is not alone (Linguistic Typology);

But isn't this is all remote history? No, because to some extent it translates into mental lexicons-and-grammars of contemporary speakers (Linguistic Typology);

How are learners of a language supposed to organise their mental lexicons and grammars so as to be in line with across-the-board constraints or dispreferences like those envisaged here? And how are these organising options supposed to remain stable from generation to generation of language learners? To answer this question, we must move beyond a merely intuitive understanding of direct causation (Glosa).

Діалогічні єдності $є$ відтворенням творчого наукового мислення автора, оскільки містять хід розгортання думки, що має на меті втягнути читача в дискусію, активізувати його увагу і критично проаналізувати отримувані відповіді.

Зауважимо також, що всі виокремлені типи інтерогативних конструкцій володіють достатнім прагматичним потенціалом і слугують для підтримання наукової дискусії та контролю над постійною увагою адресата. Вони створюють комунікативну напругу в очікуванні наступної відповіді на сформульоване питання.

Надалі виділені питальні конструкції було проаналізовано щодо їхнього прагматичного потенціалу. Беручи до уваги напрацювання попередників (В. Карасик, Д. Копил та ін.), а також ураховуючи власні спостереження, було виокремлено такі тактики аргументативної стратегії: 1) експлікативну (слугує окресленню наукової проблеми перед потенційним адресатом), 2) організації наукової дискусії (проектує наукові кроки автора в досягненні поставленої мети), 3) стимулювання наукової аргументації (виступає смисловим містком між раніше дослідженим та його подальшим альтернативним переосмисленням), 4) інтертекстуальну (збільшує ілокативну силу мовленнєвого впливу на адресата, переконує його в істинності поданої інформації), 5) актуалізації фонових знань (презентує свого роду кванти вже відомого через звернення до прецендентних текстів) та 6) прогнозування (оцінює перспективність обраної наукової проблеми та переконує у важливості розвитку наукової дискусії).

Подальший виклад власних результатів буде здійснено з огляду оцінки прагматичного потенціалу інтерогативів у реалізації аргументативної стратегії (як домінувальної в науковому дискурсі) через виокремлені тактики.

1) Тактика експлікації покликана увести читача до кола наукових проблем, зацікавити його в темі дослідження, привернути увагу до раніше не досліджуваних аспектів наукової проблеми. Із виділених мовних зразків лише12 конструкцій сприяли реалізації цієї тактики, що становить 5,9\% від загальної кількості проаналізованих речень:

At first sight, the existence of two different tiers for the sub-components of vowel comes as a surprise: why would natural language be designed that way? Why would elements be sometimes coalescent and sometimes competitive? The short answer is that we do not know (Glossa).

2) Тактика організації наукової дискусії видається важливою з огляду на ії проспективний характер. Аргументація можлива лише за логічної послідовності виконуваних завдань. Істотно, що в наукових статтях питальні речення нерідко виконують таку організаційну роль, оскільки структурують подальший виклад матеріалу відповідно до поставлених завдань. У проаналізованих прикладах (39 речень, тобто 19,1\%) інтерогативні структури представлені власне питальними реченнями (здебільшого специфікованими), що, безсумнівно, налаштовує реципієнта на інтелектуальну взаємодію 3 автором, активізує його мисленнєві операції і прогнозує передбачувані (непередбачувані) відповіді на поставлені питання. Реалізація описуваної тактики відбувається як через одиничні питання, так і через питальні комплекси:

The paper seeks to answer the following questions: (a) What is the range of functions of reduplication where it is used in predication? (b) What tendencies are there with respect to how reduplication is used in predication? (c) What iconicities are present in the predicative uses of reduplication? (d) How do the predicative functions of reduplication relate to one another? (Text\&Talk);

The research questions motivating this study are: What is the nature of social practices that allow the discursive formation of identities and hierarchy within online communities and how do those practices define the very nature of online gatherings? (Text\&Talk);

In this paper, I aim to explain 'care leaver' as an identity by answering the question: what evidence does language use in context provide for the existence of a 'care leaver' collective identity? 
Emotions evoked by brand values can be compared (with other emotions of other brand users) and the brand ideal is the standard by which the emotions become compared and integrated into (self-) conscious thought. However, does every brand community involve values and ideals? Yes, to some degree they certainly do, we believe. The hard question is, of course, how we understand this more precisely. Furthermore, what is the semiotic logic behind the way that ideals and values affect the brand community members? We will try to address these two questions in the mentioned order (Semiotica).

3) Тактика стимулювання наукової аргументації представлена найбільшим числом інтерогативів, що, ймовірно, пояснюється прагненням авторів наукових статей до створення взаємодії з читачем. Показово, що переважна більшість інтерогативних мовних формул цієї тактики була використана в основній структурній частині наукових статей (Discussion), посилюючи тим самим діалогічну взаємодію з читачем та активізуючи його увагу. Загальна кількість питальних речень, ужитих для реалізації тактики стимулювання наукової аргументації, становить 119 одиниць (58,3 \% від загальної кількості). Вони охоплюють різні типи питань, у тому числі і риторичні, що посилює прагматичний вплив на читача і водночас спонукає його до інтелектуальної дискусії з автором. Приклади мовних формул наведено нижче:

This gives rise to another question that we need to address if we do find such interpretational preferences: how do we explain these? (Gender and Language);

If distance elaboration in demonstrative pronouns is interdependent with number elaboration in nouns or personal pronouns, what about number in demonstratives itself? (Language Sciences);

The important question here is: What is the difference between comparing productivity through time (which obviously involves different corpora and also different linguistic systems) and comparing productivity through (linguistic) space as in the case with this study of borrowed Italian formatives in Maltese? (Glossa);

The foundation of these lexical assignments is not entirely clear: what rules the assignment of segments to a specific tier? Is it Saussurian arbitariness of the lexicon? (Glossa);

Can these phenomena be attributed to the relatively small size of the corpora we use? Will the perplexity of $O$ texts converge to that of $T$ texts when more data become available, or will the differences persist? To address these questions, we use the (much larger) Hansard corpus and the (even larger) Gigaword corpus. We train 4-gram language models for each Hansard and Gigaword subcorpus described in Section 3.2. (Computational Linguistics).

4) Інтертекстуальна тактика представлена незначною кількістю питальних речень (18 прикладів, що становить 8,8 \% від загальної кількості речень). Уведення таких конструкцій у канву наукової дискусії $\epsilon$ важливим конституційним кроком у побудові наукової комунікації, однак їхня питальна модальність не $\epsilon$ обов'язковою для аргументативної стратегії:

As Kendon put it: "Why should we use gesture if they are just 'words' in another form?" (Linguistic Typology);

As Hunston and Francis (2000: 103) ask (referring to the INTO-CAUSATIVE construction), "are there any limits to the creativity of speakers: can we state categorically that something cannot be said"? (Gender and Language);

The notion of "topichood" is much debated. The most widely used definition is that topic is what discourse is about. But what is "aboutness"? Is it the "totality of coherently related events, states, and referents" (Chafe 1994)? Or an "entity in focus at a given point" (Gundel et al. 1993)? (Journal of Language and Linguistic Studies).

5) Тактика актуалізації фонових знань представлена незначною кількістю інтерогативів (4 конструкції, або 2 \%), що, ймовірно, можна пояснити побоюваннями авторів за порушення комунікативного каналу. Адже реципієнтна аудиторія, хоча і уявляється ментально однорідною, не завжди може адекватно зреагувати на фонові зауваги і тим самим порушити діалогічну гармонію:

6) Тактика прогнозування є важливою для реалізації аргументативної стратегії, адже наукові досягнення тим і важливі, що залишають проблемні, дискусійні питання, які спонукають до подальшого наукового пошуку і розвитку. Проте, як засвідчують кількісні підрахунки, у реалізації цієї тактики використання інтерогативів є обмеженим (12 речень, або 5,9 \%). Хоча 3 точки зору прагматики уведення питальних речень для визначення пріоритетності наступних наукових досліджень $є$ доволі дієвим способом. Уживаючись здебільшого в прикінцевих положеннях наукових статей, інтерогативні структури створюють ілюзію наступних зустрічей із автором, з одного боку, та активізують інтелектуальну роботу реципієнта, 3 іншого, залишаючи його із власними думками щодо відповідей на поставлені запитання. Наведені нижче приклади яскраво ілюструють це:

One question, however, requires further investigation: Do MT systems based on translated-from-sourcelanguage LMs produce better translations, or do they merely generate sentences that are directly adapted to the reference set, thereby only improving a specific evaluation metric, such as Bleu? (Computational Linguistics);

The relevant question is this: Is it possible that in some manually-negated clauses HS is also, like NOD, not part of the negation, but rather contributes additional information, albeit negative, about those grammatically negated clauses? (Linguistic Typology);

A larger question is how one formally captures the range, limits and types of deviation that signal affect. Will any deviation do or are only particular deviations appropriate? Do these deviations have limits to what they can do or which affective flavors they can manifest? Do they, as in 'let's talk $x$ ', involve a constellation of factors in form, 
meaning and use? Can one predict types of deviation and how they map onto grammatical systems? Are there universal patterns or constraints? How are affective manifestations different from lexically encoded emotion ormechanisms in the iconic domain such as onomatopoeia and interjections? We hope to study the affective domain further and urge the reader to consider the questions raised here (Language Sciences).

Висновки та перспективи подальшого дослідження проблеми. Отже, підсумовуючи, констатуємо обмеженість використання інтерогативних конструкцій у науковому дискурсі, зокрема в англомовних наукових статтях. Маючи виразне емоційне забарвлення, питальні конструкції, вступають у протиріччя із конституційними ознаками наукової мови. Водночас ситуативна обмеженість аналізованих конструкцій у писемних дискурсивних практиках наукового спілкування збільшує їхній прагматичний потенціал, який працює на реалізацію аргументативної стратегії як домінувальної стратегії наукового мовлення. Проаналізований матеріал дав змогу виділити різнотипні інтерогативи англійської наукової мови, зокрема: власне питальні конструкції, риторичні запитання та діалогічні інтерогативні єдності. Залучені до аналізу мовні конструкції (усього 204 одиниці) визнано дієвими мовними формулами у реалізації основних тактик аргументативної стратегії. За кількісними підрахунками інтерогативи англомовної наукової статті найбільш повно використовують для експлікації тактики стимулювання наукової дискусії (58,3% від загальної кількості виокремлених структур). Питальні структури виявили відносно високий прагматичний потенціал у реалізації тактики організації наукового дослідження (19,1%). Натомість такі тактики аргументативної стратегії, як експлікативна, інтертекстуальна та прогнозування тяжіють до інших мовних формул їхнього представлення, про що свідчить відносно невисока чисельність питальних речень як експлікаторів цих тактик $(5,9 \%, 8,8 \%$ i 5,9\% відповідно). Зовсім обмеженим є використання питальних речень для забезпечення тактики актуалізації фонових знань (2 \% від усіх виділених одиниць).

Отримані дані не претендують на вичерпний характер і потребують екстраполяції як на інші функціональні сфери наукової статті, так і на інші жанри наукового дискурсу. Проте виявлена тенденція використання інтерогативів у реалізації аргументативної стратегії наукового дискурсу є показовою для сучасного стану наукової мови, призначеної для виваженого, неупередженого, об'єктивного, переконливого впливу на реципієнта. Водночас науковий дискурс, хоча і обмежено, проте тяжіє до використання нетипових, але прагматично сильних мовних формул, у тому числі інтерогативних конструкцій, покликаних забезпечити діалогізацію писемного наукового дискурсу і створити ефективне для реципієнта комунікативне напруження.

Перспективи подальших досліджень вбачаємо в дослідженні різнотипних питальних конструкцій як прагматично сильних мовних формул реалізації стратегій наукового дискурсу через призму формування ними позитивного впливу на реципієнта.

\section{СПИСОК ВИКОРИСТАНИХ ДЖЕРЕЛ ТА ЛІТЕРАТУРИ}

1. Іваницька Н. Б. Сучасні стратегії перекладу наукового тексту / Н. Б. Іваницька // Наукові записки Кіровоградського державного університету імені Володимира Винниченка. Серія : Філологічні науки. Кіровоград : Видавець Лисенкао В.Ф., 2016. - С. 54-58.

2. Данилевская Н. В. К вопросу об экспрессии в научном тексте / Н. В. Данилевская // Вестник Пермского университета. - 2010. - Вып. 6 (12). - С. 30-36.

3. Баган М. П. Експресивність сучасного українськомовного наукового дискурсу : межі можливого/ М. П. Баган // Вісник КНЛУ. Серія Філологія. - Том 20. 1. - 2017. - С. 9-17.

4. Ковальська Н. А. Релевантність експресивності в науково-популярних текстах економічного дискурсу / Н. А. Ковальська // Філологічні науки. Вісник Запорізького національного університету : зб. наук. праць. Запоріжжя: ЗНУ. - 2015. - № 1. - С. 376-385.

5. Онуфрієнко Г. Науковий стиль української мови: навчальний посібник з алгоритмічними приписами / Г. Онуфрієнко. - К. : Центр учбової літератури, 2009. - 392 с.

6. Кожина М. Н. Стилистика русского языка / М. Н. Кожина. - М. : Просвещеение. 1993. - 24 с.

7. Крижановская Е. М. О стереотипности компонентов коммуникативно-прагматической структуры научного текста / Е. М. Крижановская // Текст : стереотип и творчество : межвуз. сб. научн. трудов. - Пермь, 1998. C. $136-150$.

8. Cortes V. The frequency and use of lexical bundles in conversation and academic prose / V. Corets // Applied Linguistics. - 2005. - P. 56-71.

9. Swales J. M. Academic Writing for Graduate Students: Essential Tasks and Skills. Ann Arbor, 2004. - 217 p.

10. Weinrich H. Sprache, das Sprachen / H. Weinrich. - Tubimgem : Narr, 2006. -423 s.

\section{REFERENCES (TRANSLATED \& TRANSLITERATED)}

1. Ivanytska N. B. Suchasni stratehii perekladu naukovoho tekstu [Modern Strategies for Translating Scientific Text] / N. B. Ivanytska // Naukovi zapysky Kirovohradskoho derzhavnoho universytetu imeni Volodymyra Vynnychenka. Seriia: Filolohichni nauky [Research Bulletin of Kirovohrad Volodymyr Vynnychenko State University. Series : Philological Sciences ]. - Kropyvnytskyi : Publisher "KOD", 2019. - 923 p.]. - Kirovohrad: Vydavets Lysenkao V. F., 2016. - S. 54-58. 
2. Danylevskaia N. V. K voprosu ob ekspressyy v nauchnom tekste [On the Question of Expression in the Scientific Text] / N. V. Danylevsskaia // Vestnyk Permskoho unyversyteta [Scientific Papers of Perm University]. - 2010. Vyp. 6 (12). - S. 30-36.

3. Bahan M. P. Ekspresyvnist' suchasnoho ukrainskomovnoho naukovoho dyskursu : mezhi mozhlyvoho [Expression of Modern Ukrainian-Language Scientific Discourse: the Boundaries of the Possible] / M. P. Bahan // Visnyk KNLU. Seriia Filolohiia [Scientific Paper of Kyiv National Linguistic University. Philology]. - Tom 20. 1. - 2017. - S. 9-17.

4. Kovalska N. A. Relevantnist ekspresyvnosti v naukovo-populiarnykh tekstakh ekonomichnoho dyskursu [Relevance of Expressiveness in Popular Science Texts of Economic Discourse] / N. A. Kovalska // Filolohichni nauky. Visnyk Zaporizkoho natsional'noho universytetu [Philology Sciences. Scientific Papers of Zaporizzia National University] : [zb. nauk. prats'. Zaporizhzhia]. - 2015. - № 1. - S. 376-385.

5. Onufriienko H. Naukovyi styl' ukrains'koi movy [Scientific Style of the Ukrainian Language] : [navchal'nyi posibnyk z alhorytmichnymy prypysamy] / H. Onufriienko. - K. : Tsentr uchbovoi literatury, 2009. - $392 \mathrm{~s}$.

6. Kozhyna M. N. Stylystyka russkogo yazyka [Stylistics of the Russian language] / M. N. Kozhyna. - M. : Prosveshchenye. 1993. - $24 \mathrm{~s}$.

7. Kryzhanovskaya E. M. O stereotypnosty komponentov kommunykatyvno-prahmatycheskoy stryktury nauchnogo teksta [On the Stereotypes of the Components of the Communicative-Pragmatic Structure of the Scientific Text] / E. M. Kryzhanovskaia // Tekst : stereotyp i tvorchestvo [Text: Stereotype and Creativity] : [mezhvuz. sb. nauchn. trudov]. - Perm, 1998. - S. 136-150.

8. Cortes V. The Frequency and Use of Lexical Bundles in Conversation and Academic Prose / V. Corets // Applied Linguistics. - 2005. - P. 56-71.

9. Swales J. M. Academic Writing for Graduate Students : Essential Tasks and Skills. Ann Arbor, 2004. - $217 \mathrm{p}$

10. Weinrich H. Sprache, das Sprachen / H. Weinrich. - Tubimgem : Narr, 2006. -423 s.

\section{Иваницкая Н. Б., Иваницкая Н. Л. Коммуникативно-прагматический потенциал интерогатививов англоязычной научной статьи.}

В статье выяснено прагматический потенцииал интерогативних конструкций как специифических языковых формул реализации стратегии аргументации в структуре англоязычной научной статьи. На материале 100 научных статей, из которых методом сплошной выборки было отобрано 204 интерогатива, определено типологию собственно интерогативних конструкций в англоязычных научных статьях гуманитарной сферы; установлена частота употребления различных типов интерогативов 8 реализации основных тактик аргументативной стратегии научного дискурса.

Ключевые слова: аргументативная стратегия, тактика, научный дискурс, интерогатив.

\section{Ivanytska N. B., Ivanytska N. B. Communicative and Pragmatic Potential of the Interrogatives in the English Scientific Papers.}

The article focuses on the pragmatic potential of interrogative structures as specific language formulas for realizing the argumentative strategy in the structure of English scientific papers. 204 interrogative sentences were selected from the English-language academic journal papers in the humanitarian field. Methods of discursive analysis, synthesis, compositional analysis were used to reveal the peculiarities of the use of various types of interrogatives in the implementation of the basic tactics of the argumentative strategy of scientific discourse. Selected interrogative constructions were analyzed in the context of such tactics of the argumentative strategy of scientific discourse: explicative, organization of scientific discussion, stimulation of scientific argumentation, intertextual, background knowledge and forecasting. It is established that the most representative interconnecting structures in the explication of the tactics of stimulation of scientific argumentation. It happens due to the considerable pragmatic potential of interrogatives used for the creation of dialogue as a precondition for an effective communicative situation of argumentation.

However, the revealed tendency of using the interrogatives in the implementation of argumentative strategy is seemed to be indicative of the current academic language, created for a balanced, impartial, objective, convincing influence on the recipient. At the same time, scientific discourse tends to use non-typical but pragmatically strong language formulas including interrogatives having been designed to ensure the dialogue in the written academic discourse and to create an effective communicative tension for the recipient.

Key words: argumentative strategy, tactics, scientific discourse, intergroup. 